\title{
Covid-19: It's too soon to lift lockdown
}

\author{
Fiona Godlee editor in chief
}

The BMJ

Let's start with some good news. The pandemic is waning in many parts of the world, and health systems are showing how they can innovate and adapt. While we count the terrible toll of covid-19 (doi:10.1136/bmj.m1835) and continue asking hard questions of our governments (doi:10.1136/bmj.m2052), clinicians and patients are embracing new ways of doing things: virtual wards are helping to keep covid patients out of hospital (doi:10.1136/bmj.m2119), mental health services are experimenting with phone triage and virtual appointments (doi:10.1136/bmj.m2106), and doctors are supporting each other through their uniquely shared covid experience (doi:10.1136/ bmj.m1499). And in other news the NHS has launched a race and health observatory, after The BMJ's call for action to end racial inequalities (doi:10.1136/bmj.m2191).

But good news is in short supply. The world is facing a scale of challenge not seen since the second world war. The covid pandemic is now sweeping through the global south, hitting Latin America (doi:10.1136/bmj.m2182), Africa, and India, including displaced populations ravaged by war where there is no possibility of social distancing to suppress the spread of infection. Meanwhile the world's richest economy is unravelling. The eruption of deep seated anger in the US about racial injustice comes on top of an already out-of-control covid epidemic and surging unemployment. Unravelling too is the postwar consensus on international cooperation, with Donald Trump's desperate decision to cut ties with the World Health Organization (doi:10.1136/bmj.m2178).

The UK continues to fund WHO but has consistently ignored its advice (doi:10.1136/bmj.m1284). The government has now gone one step further in going against the advice of its own scientists on opening schools and ending lockdown (https:// www.theguardian.com/world/2020/may/29/coronavirussymptoms-not-isolating-sage-track-and-trace). This and the Dominic Cummings saga (https://blogs.bmj.com/bmj/2020/05/ 29/andy-cowper-the-public-health-of-politics-and-the-politics- of-public-health) have fractured the united front of the government's scientific advisory group, with several members joining the growing chorus of experts saying it's too early to ease restrictions (doi:10.1136/bmj.m2193; https://blogs.bmj. com/bmj/2020/06/01/balancing-lives-and-livelihoods-in-postcovid-19-lockdown).

In the absence of a vaccine or effective treatment (doi:10.1136/ bmj.m2018), only mass testing, contact tracing, and isolation will make it safe to exit lockdown, writes Edward Melnick in this week's Head to Head (doi:10.1136/bmj.m1924). Even John Ioannidis, who argues that lockdown has questionable benefits and multifarious harms, says the lifting of restrictions should be cautious and guided by data on prevalence and incidence (doi:10.1136/bmj.m1924). Local data in particular will be key to the stratified shielding proposed by editorialists David Spiegelhalter and George Davey Smith (doi:10.1136/bmj. m2063). Having good local data was a crucial ingredient for South Korea's successful suppression of covid-19, write Azeem Majeed and colleagues (doi:10.1136/bmj.m2084). If the UK is to avoid a second wave, all essential components of a "test, trace, and isolate" system must be in place and working well, they say. The government says the system is up and running. This is patently untrue (doi:10.1136/bmj.m2174).

Such a system could still be built with willing hands and underused expertise. But rather than identify and empower local leadership (https://blogs.bmj.com/bmj/2020/05/27/chris-hamtest-and-trace-strategy-must-value-local-leadership-to-be-asuccess), the government seems set to continue its centralised bungling and magical thinking (https://blogs.bmj.com/bmj/2020/ 05/28/public-trust-and-the-publics-health-two-sides-of-the-samecoin). More lives will be lost and economic recovery further delayed. If medical advisers are calling for a change in direction and are not being listened to, they have no option but to walk away. 